\title{
Evaluation of slagging and fouling tendency during biomass co-firing with coal in a fluidized bed
}

\author{
Paula Teixeira ${ }^{a, *}$, Helena Lopes ${ }^{a}$, Ibrahim Gulyurtlu $^{a}$, Nuno Lapa $^{b}$, Pedro Abelha ${ }^{a}$ \\ ${ }^{a}$ LNEG/UEZ, Estrada do Paço do Lumiar, 22, Ed. J, 1649-038 Lisboa, Portugal \\ ${ }^{\mathrm{b}}$ UNL-FCT-DCTB-UBiA, Quinta da Torre, 2829-516 Caparica, Portugal
}

\section{A R T I C L E I N F O}

\section{Article history:}

Received 20 April 2010

Received in revised form

2 September 2011

Accepted 5 January 2012

Available online 3 February 2012

\section{Keywords:}

Ash

Slagging

Fouling

Co-firing

Biomass

Fluidized bed

\begin{abstract}
A B S T R A C T
Over the last decades, several indices based on ash chemistry and ash fusibility have been used to predict the ash behaviour during coal combustion, namely, its tendency for slagging and fouling. However, due to the physical-chemical differences between coals and biomass, in this work only the applicability of an ash fusibility index (AFI) to the combustion and co-combustion of three types of biomass (straw pellets, olive cake and wood pellets) with coals was evaluated. The AFI values were compared with the behaviour of ash during combustion in a pilot fluidized bed and a close agreement was observed between them. For a better understanding of the mechanisms associated with bed ash sintering, they were evaluated by SEM/EDS and the elements present on the melted ash were identified. Evidences of different sintering mechanisms were found out for the fruit biomass and herbaceous biomass tested, depending on the relative proportions of problematic elements. The particles deposited on a fouling probe inserted in the FBC were analyzed by XRD and the differences between the compounds identified allowed concluding that the studied biomasses present different tendencies for fouling. Identification of $\mathrm{KCl}$ and $\mathrm{K}_{2} \mathrm{SO}_{4}$ in the deposits confirmed the higher tendency for fouling of fruit biomass tested rather than wood pellets.
\end{abstract}

(c) 2012 Elsevier Ltd. All rights reserved.

\section{Introduction}

Biomass combustion is gaining increased importance and is the subject of extensive R\&D with the aim of reducing $\mathrm{CO}_{2}$ emissions and diversification of fuel sources. There are particular aspects of biomass combustion that need to be better understood. The on-going research areas include greater utilization of agricultural biomass fuels, further improvement of power plant efficiencies and solutions to the ash related problems of certain problematic biomass [1].

The ash related problems like deposit formation, corrosion and erosion are usually responsible for malfunctioning of combustion systems. These problems may have implications on heat transfer rates and hence decrease the efficiency of the boilers. The deposits may restrict the gas flow in the boilers, through deposit accumulation and thus give rise to mechanical damages that turn the boiler unmanageable. In the limit, these problems may imply the facility shut down for maintenance.

In general it can be distinguished between two types of deposit formation: slagging and fouling. Slagging refers to the deposition taking place in the high temperature refractory sections of boilers where radiative heat transfer is dominant and occurs due to the presence of molten ashes. Fouling takes place in the convective heat transfer zones of the boiler and is due to the formation of ash deposits, while the gases cool down. Several complex mechanisms of interaction of gases

\footnotetext{
* Corresponding author. Tel.: +351 21092 4600; fax: +351 217166569.

E-mail address: paula.teixeira@lneg.pt (P. Teixeira).
} 